\title{
Growth Poles and Clusters: Are There Useful Analytical Complementarities?
}

\author{
Charis Vlados \\ Department of Economics, Democritus University of Thrace \\ PO Box 69100, Panepistimioupoli, Komotini, Greece \\ Tel: 0030-253-103-9824Ｅ-mail: cvlados@econ.duth.gr \\ School of Business, University of Nicosia \\ PO Box 24005, CY-1700, 46 Makedonitissas Avenue, CY-2417, Nicosia, Cyprus \\ Tel: 357-2284-1500Ｅ-mail: vlados.c@unic.ac.cy

\begin{abstract}
Dimos Chatzinikolaou (Corresponding author)
Department of Economics, Democritus University of Thrace

PO Box 69100, Panepistimioupoli, Komotini, Greece
\end{abstract} \\ Tel: 0030-253-103-9824Ｅ-mail: dimchatz@econ.duth.gr
}

Received: November 4, 2019 Accepted: January 30, 2020 Published: January 21, 2020

doi:10.5296/ber.v10i1.16307ＵRL: https://doi.org/10.5296/ber.v10i1.16307

\begin{abstract}
This article aims to critically review the advancements in the study of contemporary dynamics of local development under the prism of the analytical perspectives of growth poles and clusters. We proceed to a literature review of clusters and growth poles and attempt an analytical synthesis. The analysis of growth poles appears to remain within the interpretive limits of traditional economic geography, focusing mainly on the dimension of regional agglomerations. At the same time, the broader literature on clusters deals more with interdisciplinary issues in their global perspective by starting increasingly its analysis from the micro-dynamics articulated at the firm level. This article proposes a conceptual extension to the analysis of the current dynamics of local development in the framework of the "competitiveness web" that takes into account all the interdependent levels of space and actors.
\end{abstract}


Keywords: Local development, Growth poles, Clusters, Helix theory, Competitiveness web

\section{Introduction}

A field of scientific inquiry where a paradigm shift seems to unfold these days is the discipline of spatial development in different socioeconomic systems. It seems that the traditional perspective of regional analysis is being replaced gradually with the broader socioeconomic study of local dynamics, which synthesizes all the elements of space and actors that contribute to socioeconomic development (Boschma \& Frenken, 2006; Briant, Combes, \& Lafourcade, 2010; Crespo, Suire, \& Vicente, 2014).

According to Vlados et al. (2019), the traditional regional analysis seems to be saturated analytically and cannot integrate local development policy solutions capable of fostering sustainable local innovation potential and entrepreneurship. More specifically, after presenting some of the historical milestones in standard regional analysis, such as neoclassical trade models, neo-Keynesian theories of macroeconomic intervention, and neo-Marxist uneven development theories and dependency theory, the authors conclude that new theories of local dynamics address the issue of local development more thoroughly. These new local development dynamics analyses are mostly interdisciplinary, belonging to the broader discipline of evolutionary economics, in "Nelsonian" terms (Nelson et al., 2018).

The issue of industrial agglomerations in its geographic context has attracted the interest of the founders of the field of economic geography (Becattini, 1979, 1990; Marshall, 1890), while it continues to pose a challenging question (Boschma, 2015). In the changing context of local dynamics in the era of restructuring of globalization (Andrikopoulos \& Nastopoulos, 2015; Laudicina \& Peterson, 2016; Vlados et al., 2018), this study tries to find out the focal points of the concept and analysis of growth poles and the analytical model of clusters and relate them to local development dynamics. It tries to identify the critical common points and differences as well as the prospects of a future analytical convergence based on recent developments in the field of spatial socioeconomic sciences. This analysis could help build a logical path to discover new local development dynamics methodologies and conceptual tools to enrich our understanding.

\section{Methodology and Structure}

The following steps reflect the methodology of the paper:

I. First, it presents the general framework of the recent approaches to local development.

II. Second, after searching relatively recent literature, from 2010 onwards, in the "Scopus" database by including the word "growth poles" in the title of the publication, it identifies the most cited past works in these recent articles that constitute the theoretical roots of "growth poles" theory. Ten publications that function as theoretical foundations of the theory and about ten recent ones that can indicate the current theoretical trends are discussed.

III. Third, for the analysis of the clusters' theoretical perspective, a synthesis of the research made by Lazzeretti, Sedita, \& Caloffi (2014) is attempted, who venture on a 


\section{Mll Macrothink}

bibliometric analysis of clusters theory for the years 1989-2010. The authors start by identifying the founders of the theory by going as back as the contributions made by Marshall and end up to 46 publications constituting the "disseminators." They further distinguish about ten publications out of 46 with the most citations per year, which we analyzed for our research. In this paper, we supplement these "disseminators" with about ten publications that we found from the "Scopus" list based on the criterion that they cite the bibliometric analysis by Lazzeretti et al. These also are bibliometric analyses of cluster theory, and we use them to present how they conceptualize the analysis of clusters after classifying the vast literature on the subject. It is worth mentioning that cluster theory publications are overwhelmingly more than the ones having at their center the theory of growth poles, for which we did not find any corresponding extensive bibliometric analysis, which is another evidence that cluster theory literature is much more extensive than growth poles literature.

IV.Fourth, the evidence from the literature review is discussed by distinguishing convergences and divergences between the theories of "growth poles" and "clusters" in terms of local development dynamics.

V. Fifth, an attempt for a theoretical counterproposal is made in terms of "competitiveness poles," "helix theory" of local development, and the "totalizing" system of the "competitiveness web."

VI. Finally, conclusions and limitations are drawn together with a proposed framework for future research.

\section{Literature Review}

\subsection{Local Development}

The theory of local development undergoes an enrichment of its concepts and methods, including not only narrow economic dimensions but also socio-political, cultural, and ecological dimensions. The following aspects can characterize the current "qualitative transition" from traditional regional theories to local dynamics and evolutionary theories. These approaches often place the "living organization" at the center of the local system (Vlados, 2019), which interacts with the external environment dynamically.

Local development theories study the "environment of innovation," which is a local-spatial entity that is an open system to its external environment and includes local cognitive dynamics stemming from the actors hosted internally. The concept of an "innovation environment" views the socioeconomic phenomena of spatial development evolutionarily since it incorporates both innovative actions that unfold in local contexts (Aydalot, 1984). According to Aydalot (1986), local "innovation environments" are the actual innovators since creativity stems from locally accumulated knowledge that the strictly planned strategies of large corporations cannot provide. This locally accumulated knowledge, therefore, gives a chance to different socioeconomic formations on a local scale to reproduce their competitiveness and develop in globalized terms (Audretsch \& Lehmann, 2005; Balland, Boschma, \& Frenken, 2015; Carlino \& Kerr, 2014). 
Overall, local development shifts from a "top-down" to a "bottom-up" understanding, assuming that socioeconomic evolutionary processes initiate "from the bottom" and integrate all the upper levels of space (Benko \& Lipietz, 2000). To this end, all the local socioeconomic systems affect their broader regional, national, or supranational socioeconomic systems, although unequally in terms of development. According to Pike et al. (2007), no spatial-social entity distributes its dynamics evenly throughout the local system. In Marxian terms, this unequal development exists inherently in every spatial market system because there are specific areas that concentrate socioeconomic activities by creating "winning" or "losing" spatial entities (Harvey, 2006; Holland, 1976). Some scholars reposition this inequality by including more aspects that can produce and reproduce local development, such as the unequally distributed local political power (Araujo, Ferreira, Lanjouw, \& Özler, 2008), or the external investment to the local system that can keep reproducing local patterns of inequality and poverty (Tomaskovic-Devey \& Roscigno, 1997).

Local development includes conflicting elements from a social point of view, leading some analysts to highlight today's significance of politics and ideology in legitimizing interventions and addressing developmental issues in regional terms (Hadjimichalis \& Hudson, 2006, 2014). These interventions can act in favor of specific individuals or groups and marginalize others because different geographic groups compete and cooperate at the same time in this new framework of local dynamics (Cox, 1998; Cumming, Cumming, \& Redman, 2006).

Modern local development dynamics reproduce diversity and heterogeneity since various policies at the local-regional level focus on strengthening local production systems (Newman et al., 2015). According to Pike et al. (2006), policies focused on regional or local development can indeed include both "top-down" and "bottom-up" policies and other combinations such as endogenous or exogenous development. Overall, a change of "paradigm" is noticed, where the prevailing perception to foster socioeconomic systems on a local scale moves from traditional regional policy instruments towards more sophisticated and multi-level perspectives. A central priority of local development policies is how to integrate into different local systems mechanisms that can foster knowledge and innovation.

To this end, we proceed to discuss the theoretical approaches of "growth poles" and "clusters" that seem to fall into these categories of local development dynamics.

\subsection{Growth Poles}

The growth poles approach initiates from the work of Francois Perroux. Perroux $(1955,1970)$ argues that growth does not appear everywhere at the same time, but it becomes manifest at points or poles of growth, which concentrate innovations clustered around the leading industry (the "motor") that in turn dominate and gain control over the "affected industry." He suggests the existence of "clusters of industries" that include a "key industry" that can increase the output (and inputs) of another or several other industries when it increases its output (and productive inputs). This system of the cluster of industries is by itself "destabilizing," because it is a combination of oligopolistic forms, while there is also a territorial agglomeration aspect that adds its specific consequences to the key industries. 
According to Perroux, the national economy is a combination of relatively active industrial systems (motor industries, poles of geographically agglomerated industries and activities) and relatively passive industrial systems (affected industries, regions dependent on geographically agglomerated poles). The approach of Perroux is mostly of "economic spaces" rather than "geographical spaces" (Perroux, 1950). These "economic spaces" consist of centers (or poles or foci) from which centrifugal forces emanate and to which centripetal forces are attracted.

Subsequently, new theories of unbalanced growth with more specific geographic implications start to emerge upon this basis. Myrdal (1957) argues that positive growth spill-overs (the "spread effects") from more developed territories to less developed territories do not counterbalance negative growth spill-overs (the "backwash effects"). Myrdal introduces the principle of "circular cumulative causation," which implies that positive changes cause the cumulative growth process, while negative changes cause a cumulative shortening process. Hirschman (1958) argues that the existence of "growing points" or "growth poles" alone means that international and interregional inequality of growth is a necessary condition of growth itself. Hirschman proposes a two-region model of growth, arguing that the "advanced North" exerts a positive (trickling-down) effect on the "less developed South" if the two economies are complementary, while the "North" exerts negative (polarization) effects on the "South" if the two economies are competitive in structure.

Boudeville (1966) also transfers Perroux's concept of the economic space to the geographic domain by arguing that a regional growth pole is a set of expanding industries located in an urban area. A growth pole is a large city consisting of a propulsive industry, which does not necessarily employ the most significant labor force, but it has the most significant direct or indirect influence on the welfare and activity of the region. A propulsive industry has a direct and indirect dominating influence over all other activities and causes an oligopolistic industrial concentration, whereas polarization is a process of industrialization and diversification set in motion by an industry or an industrial complex.

Friedmann (1967), in his theory of polarized development, proposes a core-peripheries model, arguing that development is a process of innovation that has its origin in a relatively small number of centers of change located at points of high-potential interaction within a communication field. Development tends to spread outwards from these centers to areas where the probability of potential interaction is much lower. These dominant centers of change are core regions, while all other areas within a given spatial system are peripheral regions. According to McKee (1987), the dialectics of polarization explains why existing growth poles can become centers of stagnation. Supporting the development of service activities can mitigate the harmful effects of the changes.

Parr (1999a, 1999b), who examines growth-pole strategies as a part of regional economic planning, distinguishing four phases. A) In the early 1960s, policy-makers articulate growth poles strategies for a particular problem region setting mostly. B) In the late 1960s, this strategy extends to various types of regional or interregional problems, following a Keynesian intervention and state involvement. C) In the early 1970s, policy-makers abandon the above strategy because of the upheavals in the world and national economies and a 
reappraisal of the scope of state intervention. D) In the mid-1970s and beyond, the growth-pole strategy appears discredited for regional economic planning. Overall, the author argues that the growth-pole strategy tends to be specific, decisive, and not flexible; decision-makers often caused the strategy to be adopted before an adequate diagnosis of the regional problem was available.

More recently, Ke and Feser (2010) study the occurrence of "spread-backwash effects" on a Chinese territory by analyzing the impact of economic growth in bigger cities on smaller cities and counties, concluding that growth poles in large cities can generate both positive and negative regional growth spillovers. Christofakis and Papadaskalopoulos (2011) examine the polar concentrations in Greece and propose a sectoral policy to attract propulsive activities.

Dąbrowska and Lukomska (2011) examine the growth possibilities of "subregional" centers in Poland, which define as "somewhere in inter-metropolises areas" and try to find out whether these centers are growth poles for their surroundings in the age of growing regional polarization and a knowledge-based economy. Li et al. (2014), based on a mathematical model that takes into account the transport network and spatial structure, argue that different transportation accessibility causes differential growth and phenomena of polarization.

Smékalová et al. (2014) examine the Slovak policy for growth poles and distinguish between different types of growth poles; they argue that "innovation growth poles" allocate the most entrepreneurship support because they constitute the largest municipalities that concentrate economic activities. Bere (2015) analyzes how specific institutions developed within the growth pole policies in Romania influence this top-down government intervention. Eikeland and Nilsen (2016) link the strategies of multinational corporations with emerging growth poles, analyzing whether specific strategies can be useful in building a specialized supplier industry in a region that has developed later than the pioneer regions of the Norwegian oil and gas industry. Godlewska-Majkowska et al. (2016) present the polarization effects of special economic zones in Polish regions and suggest that the center of the polarized region can also be an "anti-growth" pole if it promotes crisis factors.

Popkova et al. (2016), who compare GDP growth between specific countries over time, suggest that specific developing countries are going to act as growth poles in the emerging post-crisis global economy. Pysar (2017) applies the "growth poles" theory by setting quantitative criteria to find which industries contribute most in some Ukraine regions, arguing that growth poles development will raise the country's overall socioeconomic level. Strat and Stefan (2017) build an index from county-level economic and social data for a specific year and argue that the Romanian economy is polarized, something that requires a new overall socioeconomic model of development that favors the weaker geographical regions and industries.

Overall, as a first conclusion, it seems that unbalanced growth and polarization among geographic territories are core ideas in the "growth poles" literature. Growth does not appear everywhere at the same time, but it becomes manifest at points or poles of growth, where a "propulsive" industry or firm dominates and gain control over the "affected industry." These polar concentrations have either negative or positive spillover effects at a spatial level, which 
the literature explains by dual, or "dialectic" schemes, such as "core-periphery" or "less developed-advanced" regions. In this context, the practice of growth poles usually emerges as a quantitative regional growth analysis. As a result, the growth pole strategy tends to be inflexible, applying mostly a top-down approach of specific sectoral scope.

\subsection{Clusters}

The theoretical approach of clusters initiates mostly from the "industrial districts" perspective. To this end, Markusen (1996) rejects the "Marshallian" or "Italianate" form of industrial district by suggesting three new types: a "hub-and-spoke" industrial district that revolves around one or more dominant externally-oriented firm; a "satellite platform" that is an assemblage of unconnected branch plants embedded in external organization links; and a "state-anchored district" that focuses on one or more public-sector institutions. Marshall had envisioned a region comprising of a locally owned firm that makes investment and production decisions locally. On the contrary, the author suggests that a locally targeted development strategy will fail to achieve its goals.

At the same time, from a strategic management perspective, Porter (1990) disseminates the "cluster" concept. According to Porter (2000), clusters are geographic concentrations of interconnected companies and institutions in a particular field and encompass an array of linked industries and other entities important to competition; they include suppliers of specialized inputs providers of specialized infrastructure. Clusters are a new kind of spatial organizational "form in between arm's-length markets on the one hand and hierarchies, or vertical integration, on the other ... clusters mitigate the problems inherent in arm s-length relationships without imposing the inflexibilities of vertical integration or the management challenges of creating and maintaining formal linkages such as networks, alliances, and partnerships. A cluster of independent and informally linked companies and institutions represents a robust organizational form that offers advantages in efficiency, effectiveness, and flexibility" (Porter, 1998, pp. 78-80).

McEvily and Zaheer (1999) argue that firms in geographical clusters that maintain networks rich in "ties" to regional institutions are well-positioned to access new information, ideas, and opportunities and, therefore, can acquire competitive capabilities. These "ties" link a focal firm to contacts in economic, professional, and social circles not otherwise accessible to the firm.

Gordon and McCann (2000) propose three models of processes that underlie spatial concentrations that are sometimes complementary and sometimes contradictory. The "model of pure agglomeration" understands the benefits of firms in the local area primarily because of their geographical proximity and not of their internal capabilities ("external economies" analysis). The "industrial-complex model" signals industrial complexes that include sets of identifiable and stable relations among firms, conceived primarily in terms of trading links. The "social-network model" suggests the existence and development of institutions as a rational response to the transactions-costs problems caused by bounded rationality and opportunism in a pure market-contracting economy. 
Malmberg and Maskell (2002) investigate the nature of spatial clustering from a knowledge-creation or learning perspective and identify two main components: the existence of the cluster and its internal organization. On the one hand, the cluster exists primarily because of the benefits of enhanced knowledge creation that occur when many collocated firms undertake similar activities. On the other hand, collocation enhances the innovative capabilities of firms and provides them with an arsenal of instruments to obtain and understand even the most subtle, elusive, and complex information.

Martin and Sunley (2003, p. 2) argue that Michael Porter's cluster theory "has become the standard concept in the field, and policy-makers the world over have seized upon Porter's cluster model as a tool for promoting national, regional, and local competitiveness, innovation, and growth." The cluster concept is overly elastic and cannot provide a universal and deterministic model on how agglomeration relates to regional and local economic growth. An association between some high-growth industries and various forms of geographical concentration does not always explain why this concentration is the cause of their economic growth.

Bathelt et al. (2004) suggest a "buzz-and-pipeline" learning-centered theory of clustering. A high-quality local "buzz" leads to a dynamic cluster because there are many actors with complementary and heterogeneous knowledge, skills, and information who interact dynamically. The "pipeline" structure, that is, extra-local sources of knowledge, connects the local cluster to the rest of the world, and a firm can establish knowledge-enhancing relations to actors outside the local cluster; local buzz helps information to spill over from one cluster firm to another.

Storper and Venables (2004) argue that economic geography involves an evolutionary tension between two opposing forces. On the one hand, remote and cheaper locations host complex and unfamiliar coordination tasks as routine activities through the codification of information, so that less "face-to-face" contact is necessary; the geographical consequence is the tendency towards de-agglomeration or dispersion of production. On the other hand, bursts of innovations create new activities that can be accomplished only by complex and unfamiliar coordination mechanisms. Nowadays, information is rapidly changing, and knowledge is tacit and, therefore, the authors predict that the mix of activities involving face-to-face and geographical co-location will continue to generate agglomeration of highly skilled individuals, firms, and bureaucracies in high-cost urban centers. In environments where information is imperfect, rapidly changing, and not easily codified (features of many creative activities), face-to-face contact is essential.

More recently, Lazzeretti et al. (2014) argue that although many analysts characterize the cluster concept "chaotic," its international and interdisciplinary success is based on three crucial features: multidisciplinary, cross-disciplinary, and global dimension. Hervas-Oliver et al. (2015) find that "distinct yet interconnected" debates shape the current evolution of the cluster literature. They notice an intersection between the management discipline and economic geography/regional studies, as well as an increasing interest in the micro-unit of analysis, and the consolidation of statistical methodologies based on spatial network analysis. 
Caloffi et al. (2018) find that from the beginning of the 1990s to 2013, keywords related to meso-level combine with keywords related to micro-level in the analysis of clusters. However, we are witnessing recently a diffusion of keywords that concern the firm and the knowledge mechanisms that enable the firm to innovate and create value. García-Lillo et al. (2018) find that in the literature of clusters and industrial districts prevails an endogenous local development paradigm. They also notice that the current literature increasingly stresses the need to open territories and to connect them with global value chains and to acquire different knowledge, renovate actors, open networks, and rejuvenate territories.

$\mathrm{Lu}$ et al. (2018) find that recent cluster studies discuss cluster phenomena from either a micro-level or meso-level. They notice that scholars and practitioners have accumulated more knowledge on why and how clusters emerge and decline, and how to utilize cluster policy to improve economic development. Sedita et al. (2018) provide bibliometric evidence that the cluster theory obeys to some evolutionary dynamics that might resemble those of scientific paradigms and find an evolutionary trajectory that appears to describe a mature concept. Chain et al. (2019) explore the literature on quantitative methods applied in the measurement of industrial clusters. They find that keywords such as "geographic concentration" and "agglomeration" occur more than the other synonyms "localization," "location," "patterns," "clusters" and "specialization" while papers studying emergent trends and new topics of the area use the word "innovation" centrally.

Overall, clusters theory also analyzes spatial concentrations, although from a knowledge-creation perspective mostly. The micro-level analysis of spatial phenomena in their global perspective seems to be gaining analytical primacy in the interpretations made by clusters theory. Typically, the literature accepts the definition that clusters of independent and informally linked companies, and institutions, represent a robust organizational form that offers advantages in efficiency, effectiveness, and flexibility (Porter, 1998). However, it seems that the clusters concept is somewhat "chaotic" because it has a multidisciplinary (to be more accurate cross-disciplinary) and global nature. It constitutes an intersection between the management discipline and economic geography/regional studies, although some theorists promote the idea that clusters theory might be a mature concept by now and an emerging scientific paradigm. In this context, it seems that policy-makers around the world have used the clusters concept of "Porterian" origin extensively to promote complex issues, such as the national, regional, and local competitiveness, innovation, and growth.

\section{Analytical Divergences and Convergences between "Growth Poles" and "Clusters"}

These central contributions to the evolution of the theoretical perspective of "growth poles" and the "clusters" concept can lead to some first conclusions. As far as the perceptions of the two theoretical perspectives are concerned, we distinguish the following points of convergence or divergence:

i The leading industry occupies a central role in the regional agglomeration phenomenon, as faced by the growth poles theory, thus creating an unavoidable polarization. On the contrary, clusters include an array of linked industries, integrating a global perspective. 
ii Both theoretical perspectives study phenomena of geographic concentrations. Growth poles theory studies mostly negative or positive spillovers at a spatial level, whereas clusters incorporate collocated firms having at the center the aspects of knowledge and innovation.

iii Growth-pole strategies as a part of regional economic planning tend to be specific, decisive, and inflexible. On the contrary, it seems that policy-makers around the world have "seized upon" Porter's cluster model to promote complex issues, such as the national, regional, and local competitiveness, innovation, and growth.

As far as recent trends are concerned and how new studies address these two theories, we draw the following observations:

a) Growth poles continue to study the majority of polarization phenomena at a geographic level. On the contrary, in clusters theory, only those studies analyzing geographic agglomerations contribute to the different geographic concentrations analysis.

b) A significant divergence in the objectives of these two interpretive approaches is also an observable fact. The analysis of clusters appears to cross different disciplines, while growth poles are limited to a quantitative regional growth analysis.

c) The micro-level analysis of phenomena in their global perspective seems to be gaining analytical primacy in the interpretation of the clusters, whereas in growth poles theory, the activity of firms and how this affects the region is absent, having mainly a top-down perspective on theory and practice. Studies such as how multinational corporation strategies affect a less-developed region are a minority in recent growth poles studies.

Overall, we can extract some general observations:

I. The discipline of economic geography gave birth to the theory of growth poles, which appears to remain within this interpretive framework boundary. On the contrary, clusters (or industrial districts, which the central body of the literature faces as synonym concept) have a multidisciplinary perspective and a strategic orientation centered on the firm.

II. The phenomena of geographic polarization that are central to the theory of growth poles do not seem as extensive in the theoretical perspective of clusters, which includes the global aspect of local agglomeration in its analyses.

III. Both approaches study how industries influence socioeconomic development, although clusters combine a global perspective of the geographic phenomenon of the firm and industry agglomerations.

IV. The theory of growth poles seems to be in a downward trend in the regional analysis as compared to the clusters' analytical perspective. A large number of bibliometric analyses that study the significantly broader literature of clusters illustrate the 
prevalence of clusters as against growth poles.

V. Finally, it seems that recent clusters analyses are heading towards a growing study of micro-dynamics, which is not the case in growth poles, which are limited to the meso domain of analysis (industry, region)

\section{Possible Synthesis and Theoretical Counterproposal: Competitiveness Poles, Helix Theory, and the Competitiveness Web}

Are there any opportunities and possibilities for synthesizing these two analytical perspectives? Starting from the observation that there is no vast conceptual contribution to growth poles such as clusters, it seems complicated for the current "paradigm" (in Kuhnian terms; Kuhn, 1962) of regional growth poles analysis to incorporate the evolutionary dynamics of local entrepreneurship. Remaining useful, the theory of growth poles continues to study "instances" of socioeconomic systems mostly by identifying quasi-static imbalances. In contrast, the evolutionary dynamics of clusters increasingly include "behavioral" knowledge-building processes within socioeconomic actors in the cluster. It seems that growth poles theory might be better to include more socioeconomic development aspects, towards a "development poles" paradigm theory and practice.

To this end, recent developments approach growth poles as "competitiveness poles," which have also been developed in France during the past years (OECD, 2011, pp. 210-211): "Competitiveness poles and competence centers are both systemic initiatives that differ from cluster initiatives. The latter are normally more business focused with an emphasis on support for exports, inter-enterprise co-operation, quality, promotion of business expenditures in $R \& D$, etc. In contrast, competitiveness poles are large and broad partnerships of industrial, public and academic research organizations located in a distinct region (occasionally inter-regional or cross-border). The best-known examples are the French competitiveness poles but a number of other countries or regions have also developed similar approaches."

Scutaru (2015, p. 165) also provides another definition for the poles of competitiveness: "The pole of competitiveness is characterized by a well defined strategy of synergistic development of all members of the pole, SMEs, research centers, universities and other institutions of education and training of the workforce, strategy based on trust and collaboration oriented through all the activities they carry out towards research and innovation. The pole of competitiveness is a creator of jobs and aims, in addition to the domestic market the international markets. Vocation and purpose of its existence in an economy is permanent innovation and sustaining economic growth."

It seems that the poles of competitiveness transform the traditional perspective of "growth poles" by approaching the theoretical contributions of clusters. Competitiveness at the local level has been studied recently by Vlados and Chatzinikolaou (2019b), who suggest perceiving the phenomenon of local competitiveness and innovation under the light of the "helix theory" (Figure 1). 


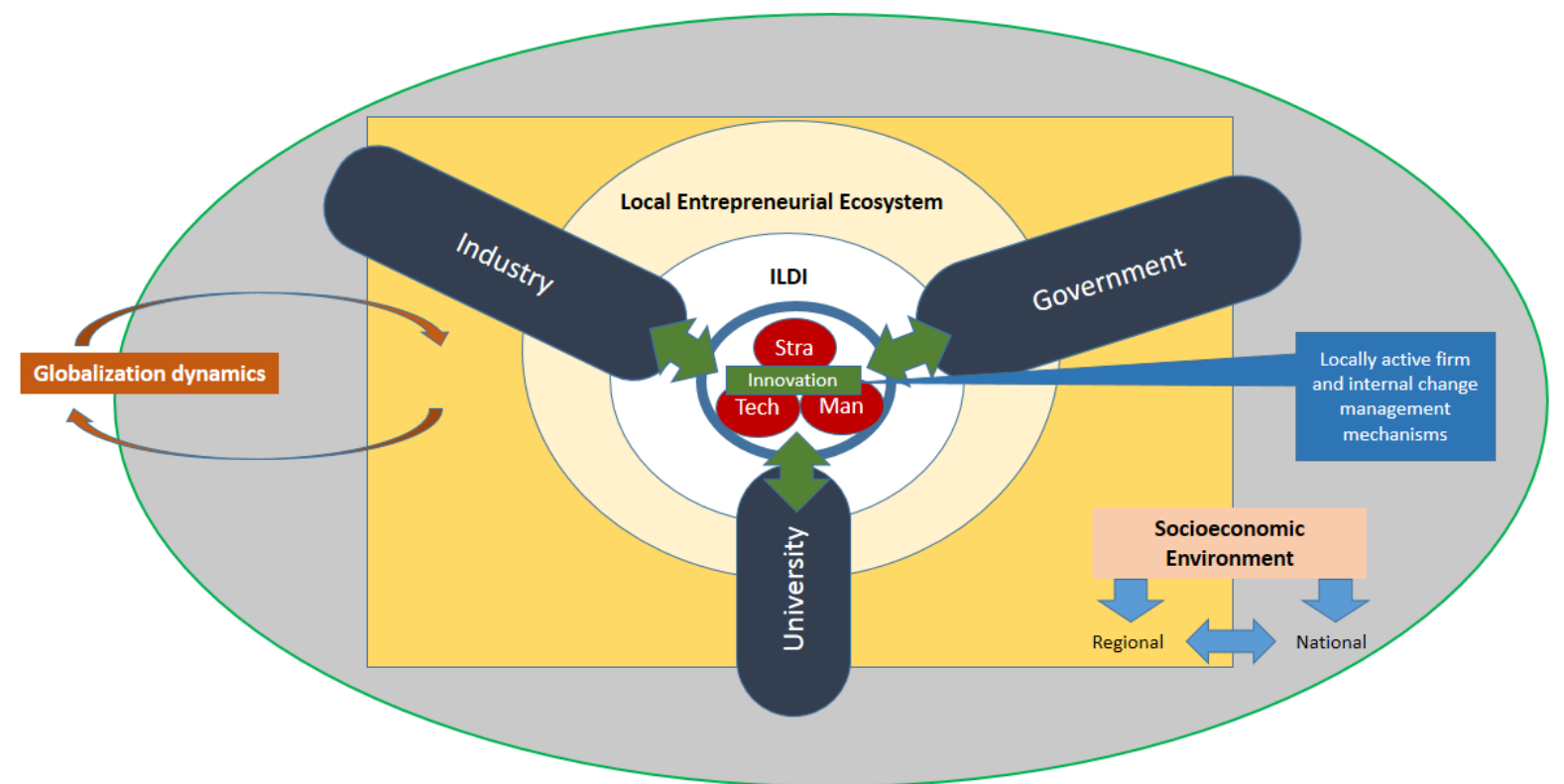

Figure 1. The helix theory in local development, based on Vlados and Chatzinikolaou (2019b)

Helix theory studies the co-evolution in today's era of globalization between the spheres of the government, the university, and the industry that generates innovation, which is primarily a byproduct of scientific knowledge (Etzkowitz \& Leydesdorff, 2000). Helix theory specifies the development model of the primary institutions of a socioeconomic system (university-government-industry) in the modern era of knowledge, which now takes an interdisciplinary character and not a mechanistic one (Carayannis \& Campbell, 2009).

These modern, and of evolutionary type, relationships between the three helices could place at their conceptual center the way the firm acts and innovates to strengthen the different local systems (Ryan, Geoghegan, \& Hilliard, 2018; Sá, Casais, \& Silva, 2018). According to Vlados and Chatzinikolaou (2019b), the establishment of intermediate institutions that aim to promote local entrepreneurship could strengthen a local entrepreneurial ecosystem in the triple helix framework: the Institutes of Local Development and Innovation (ILDI). The authors propose that the ILDIs could operate in the regions of Greece, having as a priority to diagnose the local innovative potential and how it unfolds in terms of strategy, technology, and management and, therefore, to identify the specific "physiology" of an ecosystem of firms at the local level. Then, by liaising with uncoordinated bodies at the local level (banks, chambers of commerce, and any other body that can support local development, such as local education institutions, local government, and local firms), the ILDI can provide consulting services, which aim to stimulate local innovation.

This stimulation of business innovation in the local triple helix system results from the way the firms, as socioeconomic organizations, combine their spheres of strategy, technology, and management (Stra.Tech.Man approach), within a totalizing systemic multi-level competitiveness framework: a "competitiveness web" (Figure 2). 


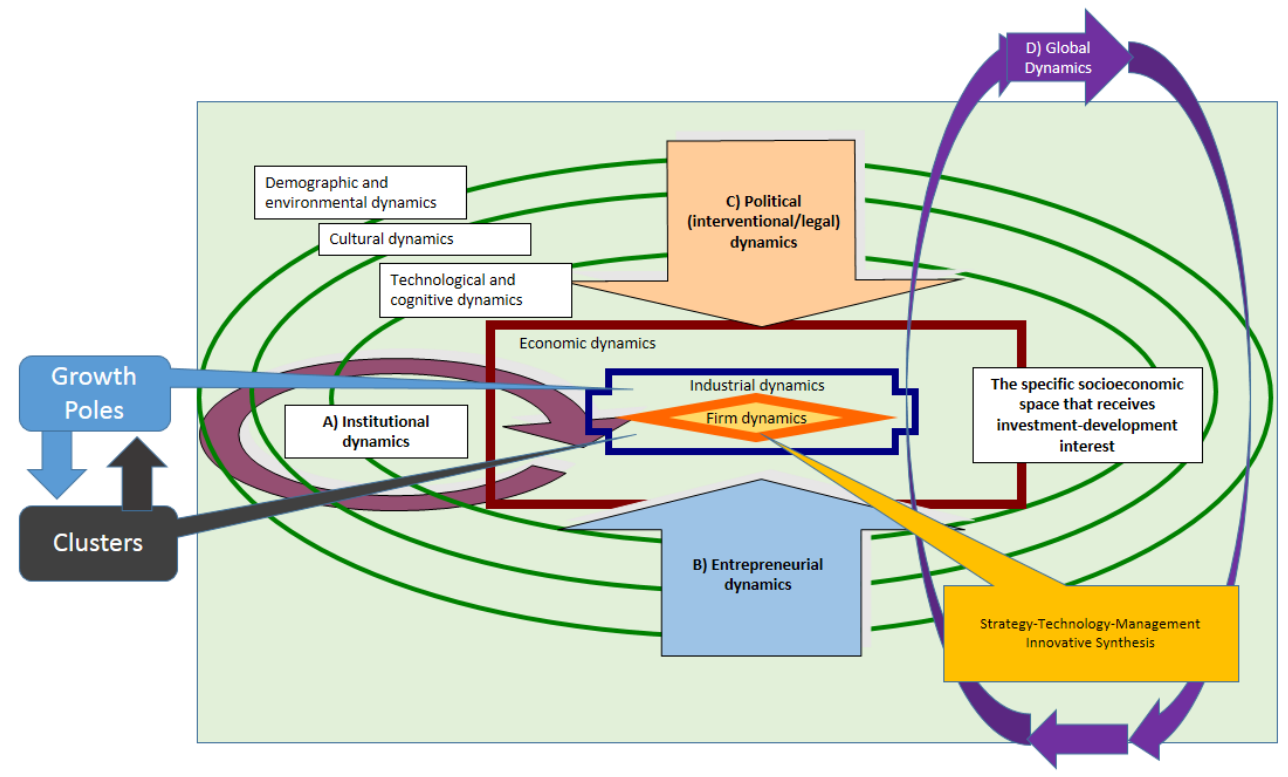

Figure 1. Competitiveness web, based on Vlados and Chatzinikolaou (2019c)

The overall socioeconomic system takes the form of a systemic "competitiveness web" (Vlados and Chatzinikolaou, 2019c), which at the center hosts the dynamics of firms in strategy-technology-management terms ("Stra.Tech.Man" approach). According to Vlados (2004), the Stra.Tech.Man approach suggests that every socioeconomic organization innovates when it synthesizes the spheres of strategy, technology, and management. Strategy corresponds to the question "where is the organization currently, where is it going, how does it go there, and why?" technology to "how does the organization draw, create, synthesize, diffuse and reproduce its means of work and know-how, and why?" while management to "how does the organization use its available resources, and why?" These questions shape the innovation of the organization internally since they concern all participating actors, both individually and cumulatively, on their synthesis.

On the proposed conceptual pattern of the competitiveness web, the different external environments interact with the internal system of the firm, which is influenced by industrial and economic dynamics. These dynamics, in turn, are co-formulated by the dynamics of the firm. In a cluster-type or growth poles-type of analysis, we could conceptualize different industrial and economic dynamics interacting with each other in different competitiveness webs. In this repositioned cluster or growth pole theoretical perspective, four spheres of analysis interact continuously with the overall external system of the firm: the institutional environment, the firm's actions, the public interventions, and the dynamics of the globalized "competitiveness webs" of the different socioeconomic systems. In this sense, the dynamics of local development acquires a sufficiently repositioned character. Every cluster or growth pole constitutes a level of competitiveness web in which dynamic interactive processes of evolutionary character take place. Therefore, the development of a local system requires multilevel policies that contain both polarization phenomena (growth poles perspective) as well as phenomena of cross-industrial agglomerations around large research centers (clusters perspective). 
For this approach to become operationalized, more research is on industrial and firms agglomerations is necessary. To this end, the operationalization of the Stra.Tech.Man approach can highlight new interventional bottom-up policies of local development. More specifically, Vlados and Chatzinikolaou (2019a) proved recently that the performance of the firms in terms of Stra.Tech.Man analysis reflects the developmental level of a less developed business ecosystem; this finding leads to a new business ecosystem policy that can foster local development by focusing on the firm-side innovation.

\section{Conclusions, Discussions, and Limitations}

In conclusion, this article attempted to investigate the analytical models of growth poles and clusters under the light of the repositioned dynamics of local development. After conducting a literature review of the two approaches, it found that the traditional industrial quantifications of regional analysis in terms of specific industries, incomes, employment, or other individual determinants cannot deal with sufficient thoroughness complex socioeconomic phenomena of contemporary development issues. Growth poles theory, as expected, focuses mainly on growth and "quantitative" issues, which would seem better to deal with them under the perspective of competitiveness (poles of competitiveness). On the contrary, the clusters concept involves multi-disciplinary reasoning and theoretical implications from a micro-perspective of development.

Through this literature review, we have also tried to come up with some elements of enriching the methodologies of studying the dynamics of local development. We propose that both a "micro-embedded helix theory" and a socioeconomic perspective in the form of a "competitiveness web" are taking the analysis of local development a step further as they take into account all components of space and actors that can lead to the insertion into a trajectory of development or underdevelopment, respectively. The evolutionary scope of Stra.Tech.Man theory, which suggests that all socioeconomic actors articulate their innovative action based on how they synthesize their spheres of strategy, technology, and management internally, in all the interdependent levels of space (local, national, and global), can also enrich clusters and growth poles theory.

These conclusions also bear some methodological constraints that we have to mention. In this study of the literature on the themes of growth poles and clusters, we did not extend our examination to specific policy applications, but mostly to conceptual determinations. The contributions analyzed can only be indicative, as they do not take full account of the vast (and in part "quasi-chaotic" for cluster analysis) literature. However, we appreciate that our study has the analytical capacity to indicate the convergence and divergence, as well as the current trends.

Future research could try to move on to a combined bibliometric analysis of the two theories, ascertaining more precisely the interpretive achievements and explanatory boundaries in the approach of clusters, growth poles, poles of competitiveness, and business ecosystems. This future research could also discuss recent developments in the evolutionary theory of the firm, which attributes to the firm's innovation the most significant developmental role in contemporary socioeconomic systems in the actual phase of global restructuring. In this 
context, this research could use the perspective of the proposed "competitiveness web" as a policy planning mechanism for calibrating developmental/innovational capacities at the local, regional, national, and supranational levels.

\section{Acknowledgment}

We would like to express our gratitude to Dr. Andreas Andrikopoulos, Associate Professor at the Department of Business Administration of the University of the Aegean, who provided useful comments during the writing of this manuscript.

\section{References}

Andrikopoulos, A., \& Nastopoulos, C. (2015). Crisis and Realism (Book published in Greek

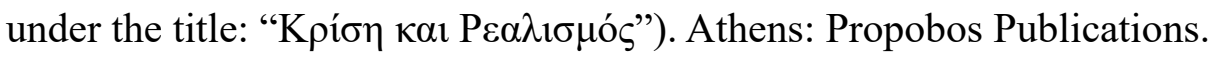

Araujo, M. C., Ferreira, F. H. G., Lanjouw, P., \& Özler, B. (2008). Local inequality and project choice: Theory and evidence from Ecuador. Journal of Public Economics, 92(5-6), 1022-1046. https://doi.org/10.1016/j.jpubeco.2007.12.005

Audretsch, D. B., \& Lehmann, E. E. (2005). Does the Knowledge Spillover Theory of Entrepreneurship hold for regions? Research Policy, 34(8), 1191-1202.

https://doi.org/10.1016/j.respol.2005.03.012

Aydalot, P. (Ed.). (1984). Crise et espace. Paris: Economica.

Aydalot, P. (1986). Milieux innovateurs en Europe. Paris: GREMI.

Balland, P.-A., Boschma, R., \& Frenken, K. (2015). Proximity and Innovation: From Statics to dynamics. Regional Studies, 49(6), 907-920.

https://doi.org/10.1080/00343404.2014.883598

Bathelt, H., Malmberg, A., \& Maskell, P. (2004). Clusters and knowledge: Local buzz, global pipelines and the process of knowledge creation. Progress in Human Geography, 28(1), 31-56. https://doi.org/10.1191/0309132504ph469oa

Becattini, G. (1979). Dal settore industriale al distretto industriale. Alcune considerazioni sull'unità d'indagine dell'economia industriale. Rivista Di Economia e Politica Industriale, $V(1), 7-21$.

Becattini, G. (1990). The Marshallian industrial district as a socio-economic notion. In F. Pyke, G. Becattini, \& W. Sengenberger (Eds.), Industrial Districts and Inter-Firm Co-operation in Italy. Switzerland: International Institute for Labour Studies.

Benko, G., \& Lipietz, A. (Eds.). (2000). La richesse des régions: La nouvelle géographie socio-économique. Paris: Presses universitaires de France.

Bere, R. C. (2015). Institutional structures in the growth pole policy from Romania. Administratie Si Management Public; Bucharest, 24, 64-86.

Boschma, R. A., \& Frenken, K. (2006). Why is economic geography not an evolutionary science? Towards an evolutionary economic geography. Journal of Economic Geography, 
6(3), 273-302. https://doi.org/10.1093/jeg/lbi022

Boudeville, J. R. (1966). Problems of regional economic planning. Edinburgh: Edinburgh University Press.

Briant, A., Combes, P.-P., \& Lafourcade, M. (2010). Dots to boxes: Do the size and shape of spatial units jeopardize economic geography estimations? Journal of Urban Economics, 67(3), 287-302. https://doi.org/10.1016/j.jue.2009.09.014

Caloffi, A., Lazzeretti, L., \& Sedita, S. R. (2018). The story of cluster as a cross-boundary concept: From local development to management studies. In F. Belussi \& J.-L. Hervas-Oliver (Eds.), Agglomeration and Firm Performance (pp. 123-137). Cham: Springer International Publishing. https://doi.org/10.1007/978-3-319-90575-4_8

Carayannis, E., \& Campbell, D. (2009). "Mode 3" and "Quadruple Helix": Toward a 21st century fractal innovation ecosystem. International Journal of Technology Management, 46(3-4), 201-234. https://doi.org/10.1504/IJTM.2009.023374

Carlino, G., \& Kerr, W. R. (2014). Agglomeration and innovation (Working Paper No. 20367). National Bureau of Economic Research. https://doi.org/10.3386/w20367

Chain, C. P., Santos, A. C. D., Castro, L. G. D., Jr., \& Prado, J. W. D. (2019). Bibliometric analysis of the quantitative methods applied to the measurement of industrial clusters. Journal of Economic Surveys, 33(1), 60-84. https://doi.org/10.1111/joes.12267

Christofakis, M., \& Papadaskalopoulos, A. (2011). The growth poles strategy in regional planning: The recent experience of Greece. Theoretical and Empirical Researches in Urban Management, 6(2), 5-20.

Cox, K. R. (1998). Spaces of dependence, spaces of engagement and the politics of scale, or: Looking for local politics. Political Geography, 17(1), 1-23.

https://doi.org/10.1016/S0962-6298(97)00048-6

Crespo, J., Suire, R., \& Vicente, J. (2014). Lock-in or lock-out? How structural properties of knowledge networks affect regional resilience. Journal of Economic Geography, 14(1), 199-219. https://doi.org/10.1093/jeg/lbt006

Cumming, G., Cumming, D. H. M., \& Redman, C. (2006). Scale mismatches in social-ecological systems: Causes, consequences, and solutions. Ecology and Society, 11(1). https://doi.org/10.5751/ES-01569-110114

Dąbrowska, A., \& Łukomska, J. (2011). Subregional growth poles in the competition for development factors. Miscellanea Geographica - Regional Studies on Development, 15(1), 133-151. https://doi.org/10.2478/v10288-012-0009-2

Eikeland, S., \& Nilsen, T. (2016). Local content in emerging growth poles: Local effects of multinational corporations' use of contract strategies. Norsk Geografisk Tidsskrift Norwegian Journal of Geography, 70(1), 13-23.

https://doi.org/10.1080/00291951.2015.1108361 
Etzkowitz, H., \& Leydesdorff, L. (2000). The dynamics of innovation: From National Systems and "Mode 2" to a Triple Helix of university-industry-government relations. Research Policy, 29(2), 109-123. https://doi.org/10.1016/S0048-7333(99)00055-4

Friedmann, J. (1967). A general theory of polarized development (Urban and regional advisory program in Chile). Santiago, Chile: The Ford Foundation.

García-Lillo, F., Claver-Cortés, E., Marco-Lajara, B., Úbeda-García, M., \& Seva-Larrosa, P. (2018). On clusters and industrial districts: A literature review using bibliometrics methods, 2000-2015. Papers in Regional Science, 97(4), 835-861. https://doi.org/10.1111/pirs.12291

Godlewska-Majkowska, H., Komor, A., \& Typa, M. (2016). Special economic zones as growth and anti-growth poles as exemplified by Polish regions. Entrepreneurial Business and Economics Review, 4(4), 189-212. https://doi.org/10.15678/EBER.2016.040412

Gordon, I. R., \& McCann, P. (2000). Industrial clusters: Complexes, agglomeration and/or social networks? Urban Studies, 37(3), 513-532. https://doi.org/10.1080/0042098002096

Hadjimichalis, C., \& Hudson, R. (2006). Networks, regional development and democratic control. International Journal of Urban and Regional Research, 30(4), 858-872.

https://doi.org/10.1111/j.1468-2427.2006.00687.x

Hadjimichalis, C., \& Hudson, R. (2014). Contemporary crisis across Europe and the crisis of regional development theories. Regional Studies, 48(1), 208-218.

https://doi.org/10.1080/00343404.2013.834044

Harvey, D. (2006). The limits to capital. London; New York: Verso.

Hervas-Oliver, J.-L., Gonzalez, G., Caja, P., \& Sempere-Ripoll, F. (2015). Clusters and industrial districts: Where is the literature going? Identifying emerging sub-fields of research. European Planning Studies, 23(9), 1827-1872.

https://doi.org/10.1080/09654313.2015.1021300

Hirschman, A. O. (1958). The strategy of economic development. New Haven; London: Yale University Press.

Holland, S. (1976). Capital versus the regions. London: Macmillan. https://doi.org/10.1007/978-1-349-15773-0

Ke, S., \& Feser, E. (2010). Count on the growth pole strategy for regional economic growth? Spread-backwash effects in greater central China. Regional Studies, 44(9), 1131-1147. https://doi.org/10.1080/00343400903373601

Kuhn, T. S. (1962). The structure of scientific revolutions (3rd edition: 1996). Chicago, IL: University of Chicago Press.

Laudicina, P. A., \& Peterson, E. R. (2016). From Globalization to Islandization (p. 26). [Online] Available:

https://www.atkearney.com/web/global-business-policy-council/article?/a/from-globalizationto-islandization 
Lazzeretti, L., Sedita, S. R., \& Caloffi, A. (2014). Founders and disseminators of cluster research. Journal of Economic Geography, 14(1), 21-43. https://doi.org/10.1093/jeg/lbs053

Li, Y., Lu, D., \& Tian, Y. (2014). Modeling corridor and growth pole coevolution in regional transportation network. Transportation Research Record: Journal of the Transportation Research Board, 2466(1), 144-152. https://doi.org/10.3141/2466-16

Lu, R., Reve, T., Huang, J., Jian, Z., \& Chen, M. (2018). A literature review of cluster theory: Are relations among clusters important? Journal of Economic Surveys, 32(4), 1201-1220. https://doi.org/10.1111/joes.12255

Malmberg, A., \& Maskell, P. (2002). The elusive concept of localization economies: Towards a knowledge-based theory of spatial clustering. Environment and Planning A: Economy and Space, 34(3), 429-449. https://doi.org/10.1068/a3457

Markusen, A. (1996). Sticky places in slippery space: A typology of industrial districts. Economic Geography, 72(3), 293-313. https://doi.org/10.2307/144402

Marshall, A. (1890). Principles of economics. London: Macmillan.

Martin, R., \& Sunley, P. (2003). Deconstructing clusters: Chaotic concept or policy panacea? Journal of Economic Geography, 3(1), 5-35. https://doi.org/10.1093/jeg/3.1.5

McEvily, B., \& Zaheer, A. (1999). Bridging ties: A source of firm heterogeneity in competitive capabilities. Strategic Management Journal, 20(12), 1133-1156.

https://doi.org/10.1002/(SICI)1097-0266(199912)20:12<1133::AID-SMJ74>3.0.CO;2-7

McKee, D. L. (1987). On services and growth poles in advanced economies. The Service Industries Journal, 7(2), 165-175. https://doi.org/10.1080/02642068700000017

Myrdal, G. (1957). Economic theory and underdeveloped regions. New York: Harper \& Row.

Nelson, R., Dosi, G., Helfat, C., Winter, S., Pyka, A., Saviotti, P., ... Dopfer, K. (2018). Modern evolutionary economics: An overview. Cambridge: Cambridge University Press. https://doi.org/10.1017/9781108661928

Newman, B. J., Johnston, C. D., \& Lown, P. L. (2015). False consciousness or class awareness? Local income inequality, personal economic position, and belief in American meritocracy. American Journal of Political Science, 59(2), 326-340.

https://doi.org/10.1111/ajps.12153

OECD. (2011). OECD reviews of regional innovation regions and innovation policy. OECD Publishing.

Parr, J. B. (1999a). Growth-pole strategies in regional economic planning: A retrospective view: Part 1. Origins and advocacy. Urban Studies, 36(7), 1195-1215.

https://doi.org/10.1080/0042098993187

Parr, J. B. (1999b). Growth-pole strategies in regional economic planning: A retrospective view: Part 2. Implementation and outcome. Urban Studies, 36(8), 1247-1268. 
https://doi.org/10.1080/0042098992971

Perroux, F. (1955). Note sur les notion de pole de croissance. Economie Appliquee, 7(1-2), 307-320.

Perroux, F. (1970). Note on the concept of growth poles. In D.L. McKee, R. D. Dean, \& W. H. Leahy (Eds.), Regional Economics: Theory and Practice (pp. 93-103). New York: Free Press.

Pike, A., Rodríguez-Pose, A., \& Tomaney, J. (2006). Local and regional development. London : New York: Routledge, Taylor \& Francis Group.

https://doi.org/10.4324/9780203003060

Pike, A., Rodríguez-Pose, A., \& Tomaney, J. (2007). What kind of local and regional development and for whom? Regional Studies, 41(9), 1253-1269. https://doi.org/10.1080/00343400701543355

Popkova, E., Meshkova, S., Karpunina, E., Karpushko, E., \& Karpushko, M. (2016). Developing countries as new growth poles of post-crisis global economy. Contemporary Economics, 10(2), 175-186. https://doi.org/10.5709/ce.1897-9254.208

Porter, M. (1990). The competitive advantage of nations (First Free Press Edition 1990). New York: Free Press. https://doi.org/10.1007/978-1-349-11336-1

Porter, M. (1998). Clusters and the new economics of competition. Harvard Business Review, 76(6), 77-90.

Porter, M. (2000). Location, competition, and economic development: Local clusters in a global economy. Economic Development Quarterly, 14(1), 15-34.

https://doi.org/10.1177/089124240001400105

Pysar, N. (2017). Application of the methodology for determining the "growth poles" of the region's industrial economy in the system of public administration. Problems and Perspectives in Management, 15(4), 72-85. http://dx.doi.org/10.21511/ppm.15(4).2017.07

Ryan, P., Geoghegan, W., \& Hilliard, R. (2018). The microfoundations of firms' explorative innovation capabilities within the triple helix framework. Technovation, 76-77, 15-27. https://doi.org/10.1016/j.technovation.2018.02.016

Sá, E., Casais, B., \& Silva, J. (2018). Local development through rural entrepreneurship, from the triple helix perspective: The case of a peripheral region in northern Portugal. International Journal of Entrepreneurial Behavior \& Research, 21(1), 5-26.

https://doi.org/10.1108/IJEBR-03-2018-0172

Scutaru, L. (2015). Innovative cluster or competitiveness pole? Ecoforum Journal, 4(1), 163-167.

Sedita, S. R., Caloffi, A., \& Lazzeretti, L. (2018). The invisible college of cluster research: A bibliometric core-periphery analysis of the literature.

https://doi.org/10.1080/13662716.2018.1538872 
Smékalová, L., Hrabinová, S., \& Habuda, M. (2014). Spatial distribution of competitiveness support in the Slovakia in relation to growth poles and small and medium enterprises. Scientific Papers of the University of Pardubice, Series D: Faculty of Economics and Administration, 21(30), 95-106.

Storper, M., \& Venables, A. J. (2004). Buzz: Face-to-face contact and the urban economy. Journal of Economic Geography, 4(4), 351-370. https://doi.org/10.1093/jnlecg/lbh027

Strat, V. A., \& Stefan, C. (2017). The growth poles and the lagging regions of Romania - a county level approach for 2015 -. Management \& Marketing. Challenges for the Knowledge Society, 12(3), 456-473. https://doi.org/10.1515/mmcks-2017-0028

Tomaskovic-Devey, D., \& Roscigno, V. J. (1997). Uneven development and local inequality in the U.S. south: The role of outside investment, landed elites, and racial dynamics. Sociological Forum, 12(4), 565-597. https://doi.org/10.1023/A:1022174707289

Vlados, C. (2004). La dynamique du triangle stratégie, technologie et management: L'insertion des entreprises grecques dans la globalisation (Thèse de doctorat de Sciences Économiques, Université de Paris X-Nanterre). [Online] Available:

http://www.theses.fr/2004PA100022

Vlados, C. (2019). Change management and innovation in the "living organization": The Stra.Tech.Man approach. Management Dynamics in the Knowledge Economy, 7(2), 229-256. https://doi.org/10.25019/MDKE/7.2.06

Vlados, C., \& Chatzinikolaou, D. (2019a). Business ecosystems policy in Stra.Tech.Man terms: The case of the Eastern Macedonia and Thrace region. Journal of Entrepreneurship, Management and Innovation, 15(3), 163-197. https://doi.org/10.7341/20191536

Vlados, C., \& Chatzinikolaou, D. (2019b). Developments on helix theory: Exploring a micro-evolutionary repositioning in Stra.Tech.Man terms. International Journal of World Policy and Development Studies, 5(10), 87-99. https://doi.org/10.32861/ijwpds.510.87.99

Vlados, C., \& Chatzinikolaou, D. (2019c). Methodological redirections for an evolutionary approach of the external business environment. Journal of Management and Sustainability, 9(2), 25-46. https://doi.org/10.5539/jms.v9n2p25

Vlados, C., Deniozos, N., Chatzinikolaou, D., \& Demertzis, M. (2018). Towards an evolutionary understanding of the current global socio-economic crisis and restructuring: From a conjunctural to a structural and evolutionary perspective. Research in World Economy, 9(1), 15-33. https://doi.org/10.5430/rwe.v9n1p15

Vlados, C., Deniozos, N., Chatzinikolaou, D., \& Digkas, A. (2019). From traditional regional analysis to dynamics of local development: Foundations and theoretical reorientations. International Journal of Regional Development, 6(1), 1-38.

https://doi.org/10.5296/ijrd.v6i1.14230 


\section{Note for the Reader}

This is an extended and enriched version of the article that the authors presented in the international scientific conference "ICABE 2019" under the title "Theoretical evolution of growth poles and clusters analysis: Analytical divergences and convergences."

\section{Copyright Disclaimer}

Copyright for this article is retained by the author(s), with first publication rights granted to the journal.

This is an open-access article distributed under the terms and conditions of the Creative Commons Attribution license (http://creativecommons.org/licenses/by/3.0/). 